\title{
Article
}

\section{Using the UK general offender database as a means to measure and analyse Organised Crime.}

Kirby, Stuart, Francis, Brian, Humphreys, Leslie and Soothill, Keith Available at http://clok.uclan.ac.uk/13515/

Kirby, Stuart ORCID: 0000-0002-3049-1248, Francis, Brian, Humphreys, Leslie and Soothill, Keith (2016) Using the UK general offender database as a means to measure and analyse Organised Crime. Policing: An International Journal of Police Strategies \& Management, 39 (1). pp. 78-94. ISSN 1363-951X

It is advisable to refer to the publisher's version if you intend to cite from the work. http://dx.doi.org/10.1108/PJPSM-03-2015-0024

For more information about UCLan's research in this area go to http://www.uclan.ac.uk/researchgroups/ and search for <name of research Group>.

For information about Research generally at UCLan please go to http://www.uclan.ac.uk/research/

All outputs in CLoK are protected by Intellectual Property Rights law, including Copyright law. Copyright, IPR and Moral Rights for the works on this site are retained by the individual authors and/or other copyright owners. Terms and conditions for use of this material are defined in the policies page.

\section{CLoK}

Central Lancashire online Knowledge www.clok.uclan.ac.uk

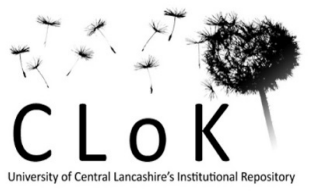




\title{
Using the UK general offender database as a means to measure and analyse Organised Crime.
}

Professor Stuart Kirby (UCLan), Professor Brian Francis (Lancaster University), Dr Les Humphreys (Lancaster University).

\begin{abstract}
Purpose

Organised Crime is notoriously difficult to define and measure, resulting in limited empirical evidence to inform policy makers and practitioners. This study explores the feasibility of identifying a greater number of organized crime offenders, currently captured (but invisible), within an existing national general crime database.

\section{Methodology}

All 2.1 million recorded offenders, captured over a four year period on the UK Police National Computer (PNC), were filtered across three criteria associated with organized crime (co-offending, commission of specific offences, three years imprisonment or more). The 4109 'organized crime' offenders, identified by the process, were compared with 'general' and 'serious' offender control groups across a variety of personal and demographic variables.
\end{abstract}

\section{Findings}

Organized crime prosecutions are not random but concentrate in specific geographic areas and constitute $0.2 \%$ of the offender population. Offenders can be differentiated from general crime offenders on such measures as: criminal onset age, offence type and criminal recidivism.

\section{Research implications}

Using an offence based methodology, rather than relying on offenders identified through police proactive investigations, can provide empirical information from existing data sets, across a diverse range of legislative areas and cultures. This allows academics to enhance their analysis of organized crime, generating richer evidence on which policy makers and practitioners can more effectively deliver preventative and disruptive tactics.

\section{Originality}

This is the first time an 'offence based' methodology has been used in differentiating organised crime from other offenders in a general crime database. 


\section{Introduction}

The ability to measure crime is critical to understanding patterns of offending across people, space and time (Sullivan \& McGloin, 2014:446). Whilst measuring crime can be problematic, this challenge is exacerbated with organised crime, which is a contested concept, notoriously resistant to definition and measurement (Levi, 2012). This is of particular concern as organised crime is a global problem affecting the stability, security and general well being of many nations (Wright, 2013). Further, whilst volume crime has reduced across the developed world during the $21^{\text {st }}$ Century, this trend is not observed in organised crime (Brocklesby, 2012).

Few would argue high quality information is integral to generating effective policy and practitioner interventions. Whilst the International Crime Victim Survey (ICVS) has shown it is possible to highlight general crime trends and crime type variance across 30 countries (van Dijk, 2007), this facility is absent in organised crime. Although a transnational phenomenon, international comparative data is unavailable to inform decision-making due to a lack of standardized data categories. There have been some limited attempts to use more innovative means to establish wider understanding of emerging and more diffuse global problems. For example Transparency International (2004) and the World Economic Forum (2004) have collated views from the business world as to the extent of extortion and corruption, leading to the formulation of the Organised Crime Perception Index. Of course perception surveys can be criticized as to their efficacy (Galtung, 2006), therefore more tangible indicators have emerged, such as unsolved homicides, as a crude 
method to try and indicate levels of mob related homicide. Indeed these objective and subjective measures have since been merged to generate the Composite Organized Crime Index, providing a rudimentary international picture to stimulate some level of debate around regional differences (van Dijk, 2007:138).

Unfortunately empirical information remains underdeveloped, and even within individual countries the measurement of organised crime is difficult. The authors could not discover any country that separated organised crime offenders within a general offender database; all offenders being recorded against the primary offence(s) for which they were convicted (e.g. drug trafficking, fraud). Also, this area is generally neglected by victimization surveys as they are predominantly used to measure crimes that have a direct and visible impact on the individual. Therefore, for academics with a particular interest in organised crime, the data is difficult to find, predominantly sourced from observations, interviews and the retrieval of stored information (von Lampe, 2012:181), emanating from proactive police investigations (van Koppen et al. 2010). Although law enforcement agencies guard this information closely due to operational security, when available it has some methodological limitations. As it uses an 'offender centred' approach, it can only harvest those offenders for whom a successful investigation is possible. Unsurprisingly, when coupled with the hidden nature of organised crime, and the physical dangers surrounding academic scrutiny, the actual number of available subjects is limited. This generates concerns that: (i) less visible forms of organised crime (as well as more sophisticated offenders) evade analysis; (ii) the full range of organised crime prosecutions are absent from the data; and (iii) the lack of 
standardization in data collection prevents comparative analysis (von Lampe, 2012:186). As such the associated research methodology has become diverse and diluted, criticized by commentators from the Netherlands, Germany, Canada, UK, Belgium and Europol (Tusikov, 2012:102).

Faced with the methodological and resource challenges of measurement, this study provides a new, alternative approach. It is based on the simple rationale that any nation maintaining a national database captures all offender criminal convictions which contain a significant subset of organised crime offenders emanating from a range of prosecuting agencies. Using this type of secondary data provides increased accessibility to data at reduced costs. However, the critical challenge with this new approach is how to differentiate these offenders based on a clear conceptual understanding (Tusikov, 2012). The next stage of this study reviews the academic literature in an effort to identify these variables.

Striving towards a pragmatic means to identify 'organised crime offenders' in the applied environment

Existing definitions would be an obvious place to start when attempting to separate organised crime offenders from others; however this is 'one of the most contested terms in academic criminology' (Sheptyki, 2003: 490). Two examples, a decade apart, illustrate this problem. The United Nations defined OCGs as a "structured group of three or more persons existing for a period of time and acting in concert with the aim of committing one or more serious crimes or offences in order to obtain, directly or indirectly, a financial or other material benefit" (UNODC 2004:5). The latest 
iteration of the UK government definition describes it as, 'serious crime, planned, coordinated and conducted by people working together on a continuing basis. Their motivation is often, but not always, financial gain' (Home Office, 2013:14). As can be seen variances exist in the comparison, with ambiguous elements from both (e.g. 'period of time', 'material benefit'), preventing consistent measurement. Other commentators have tried to be more specific, using such criteria as: (i) each individual having specific appointed tasks; (ii) operating across borders; and (iii) using commercial or business like structures (van der Heijden, 1996). However, even if these criteria were sufficient to define organised crime, it is thought this level of detail would be impractical to record on national systems. However, this study will review the academic literature, once more, in an attempt to identify the lowest level of common denominators that can differentiate organised crime offenders from others on a general offender database.

Perhaps the most durable depiction of organised crime is as a distinct and hierarchical group of criminals, such as the Costra Nostra (Cressey, 1969); however this description now appears inadequate (Levi, 2012). Smith (1991) observes the process is amorphous, being difficult to establish where 'shady dealing' stops (often epitomized by financial traders) and organised crime starts, with others highlighting the 'strong interdependencies between licit and illicit economies' (Edwards \& Gill ,2003:60). It therefore appears any filter should be sufficiently wide to encompass all prosecutions synonymous with organised crime, supporting an 'offence' rather than an 'offender' based approach. 
A review of approximately 180 organised crime definitions compiled by von Lampe, (2015), illustrates such offenders can be differentiated from general offenders, due to the level of serious and systematic behavior that creates disproportionate harm. The UK National Criminal Intelligence Service (NCIS, 2005:1.1) was the first to quantify 'seriousness', highlighting those crimes committed '....for substantial profit or gain, for which a person aged 21 or over on first conviction could expect to be imprisoned for three or more years' (Gilmour, 2008). Indeed, using a period of incarceration to define seriousness has been utilized in UK legislation (Police Act 1997, Sec. 93(4)), and by other international agencies, although the actual period of incarceration can fluctuate (Weenink et al. 2004). As such, incarceration appears a pragmatic criteria to depict seriousness in the filtering process.

Specifying the type of crime appears a more difficult task. Although organised crime is typically defined as motivated by profit (Savona, 2014; Home Office, 2013), on-line pedophile rings (who swop, rather than sell images), show that this concept needs to be interpreted as widely as possible. As such, one way to navigate this ambiguity is to list specific offences that epitomize 'organised crime'. This approach has been criticized by some academics (Fickenauer, 2005), who argue most criminal offences can be committed with co-offenders, although not viewed as a criminal organization. However, a review of current definitions (von Lampe, 2015) illustrates the United Nations, together with a number of governments (notably the US and Australia), continue to list offence types. These often describe general categories, such as drug and people trafficking, prostitution, and cybercrime, which are often coupled to a caveat explaining that the list is not exhaustive (Australian Crime Commission, 2013). 
In essence this study argues generating specific offence criteria, to describe offences associated with organised crime, is a useful way to differentiate this type of offender from the general offending population. As such, it will serve as the second filter mechanism used in this process.

Any exploration of the literature inevitably leads to discussions surrounding the structure of OCGs. The United Nations has tried to explain OCG through the construction of five typologies, with the 'standard' or 'type1 hierarchy' (UNICP, 2000:75), synonymous with La Cosa Nostra (Finckenauer, 2005:63). Such OCGs are characterized by: a rigid leadership and hierarchical structure; having a strong group identity; governing identifiable territory; and using corruption, racketeering and violence to achieve their criminal goals, as well as maintaining internal discipline (UN Centre for International Crime Prevention, 2000). Many commentators argue the type 1 hierarchical model is an outdated notion, built upon a 'faulty paradigm' (Standing, 2003:36), a supposition endorsed by Finckenauer (2005:65) who points out, 'What we more commonly see are loosely affiliated networks of criminals who coalesce around certain criminal opportunities. The structure of these groups is much more amorphous, free floating, and flatter, and thus lacking in a rigid hierarchy'. Similarly Duijin et al. (2014:1) highlight that studies over the previous ten years have increasingly shown organised crime is built on flexible and nonhierarchical social networks that form collectives. From these discussions we can discern that a variety of individuals engage in organised crime, facilitated through a variety of structures. Again, examining von Lampe's (2015) collection of 180 definitions almost all allude to co-offending, with the majority referring to groups, 
gangs or associations. However, eight of the definitions specifically mention three or more offenders, whilst a further eighteen definitions referred to two or more offenders. As such, the presence of co-offenders will serve as the third filtering criteria.

In summary, no current definition or distinct criteria exists that can be used to differentiate the organised crime offender from other offenders, within existing national databases, due to the conceptual vagueness surrounding organised crime. However, it should be remembered that the term 'organised crime' was primarily generated to assist policy makers, investigators, and the wider Criminal Justice System, identify and tackle a more serious and professional criminal. Encouragingly, many areas of definitional consensus exist, with 'seriousness', 'offence type', and 'co-offending', appearing to be the minimum common denominators in separating those who commit 'organised crime' from the general offending population.

\section{Methodology}

As highlighted earlier, the aim is to use secondary data from existing databases to measure organised crime. To do this a methodology is needed that primarily provides an offence rather than an offender based approach, which enables the extraction of organised crime offenders from a general population of offenders following their criminal sanction. To provide a sound test of feasibility, this is a national study, using records obtained from the Police National Computer (PNC). The PNC collates various systems, including offender sanctions for offences 
commissioned in Scotland, England and Wales. It has been extensively used to support studies relating to offender and offence trends.

The initial sample download provided anonymous data for all offenders who had registered a sanction between 2007 and 2010. A sanction relates to a criminal court conviction or an official police caution, warning, or reprimand in relation to a specific offence. The dataset contained $20,752,827$ individual sanctions for offences relating to $2,170,206$ offenders. To identify organised crime offenders: offence type, seriousness, and co-offending, serve as the three critical filters to operationalize the methodology. Importantly, these selection variables are conceptually simple and, thus, can be identified within the constraints of the database.

The first filter was the most problematic and related to the type of offence the offender had committed. Organised crime offences have previously been discussed at a generic level, e.g. drugs offences, fraud, cybercrime (Wright, 2013), which was insufficient detail. Here specific decisions had to be made across each of the Home Office list of notifiable offences (over 2500 separate offence codes). The authors inspected each offence code and decided whether each was 'likely' or 'possibly' related to OC. For example, the offence of Trafficking for Sexual Exploitation (Home Office code 72.01) was considered as a likely offence for which a large proportion of convictions would be related to OC. Conversely, convictions for the offence of Supplying or Offering to Supply Cannabis (Home Office code 92.41) were considered as convictions that may possibly be the result of organised crime, dependent on the level of seriousness and whether they involved co-offending e.g. it may range 
between a significant shipment of cannabis to the supply of a small amount of home grown cannabis to a friend. One of the authors, who had extensive law enforcement experience within serious organised crime, consulted with law enforcement personnel to generate this list. Further, the study was assisted by an external and independent scrutiny group (incorporating practitioners, policy makers and researchers) generated by the UK Home Office to assist in quality assurance. The validation process left a list of 46 offence codes which were 'likely' to involve organised crime and a further 139 offence codes that were 'possibly' an organised crime (Appendix A). Relying solely on this criterion could generate too many false positives (sanctions for offences that were not related to serious organised crime); therefore the other two filters were also introduced to help triangulate the search.

The second filter reflected 'seriousness'. The literature review identified that a period of imprisonment, fluctuating between three and five years, had previously been used to identify 'seriousness'. In this study, the lesser period was used, maintaining consistency with English legislation and policy. The final selection filter replicated the most common variable described within the definitions of organised crime - the involvement of more than one offender, so selected offenders who had been convicted with at least one other co-offender, at the same sentencing occasion was used. In summary, organised crime offenders were differentiated from others on the database as those who, between the target period of 2007-2010, had been i) convicted of a specified offence assessed as a 'likely' or 'possible' organised crime offence; ii) sentenced to a minimum period of three years' imprisonment; and iii) had been convicted with at least one co-offender. 
To establish whether this sample of organised crime offenders were sufficiently distinct from other types of offenders the study adopted a retrospective case control design with two control or comparison groups, formed by extracting two further offender samples from the database and collecting complete criminal conviction histories. The first comparison group consisted of an identical number of randomly generated general crime offenders who had received a criminal sanction between 2007-2010 for an offence that was not amongst the listed organised crimes. However, it was also of interest to know whether organised crime offenders were different from other serious offenders who received custodial sentences of the same order, but who did not satisfy the other criteria. Therefore a second comparison group was formed who had received custodial sentences of three years or more during the same period but had not been convicted with a co-offender, nor did their offence relate to one of the specified organised crime offences. All three samples were around the same size, recommended in retrospective case control design (Cole, 1979). Following data cleansing this left $n=4109$ in the Organised Crime sample; $n=$ 4109 in the Serious Crime sample; and $n=4090$ in the General Crime sample.

\section{Statistical methods}

The statistical analysis had three objectives. The first objective was descriptive and aimed to identify the general characteristics, demographics and offending behavior of the organised crime offenders. The second objective was to examine the spatial distribution of organised crime offenders. The final analytical objective was to establish whether it was possible to distinguish the organized crime offenders from 
the two control groups - both on demographic variables and on criminal career variables.

The second objective tested the null hypothesis of no difference in the rank orders using Kendall's coefficient of concordance W, carrying out a chi-squared test on the transformed W statistic. The third objective, we adopted null hypotheses of no difference between the organised crime offenders and the two control groups. The categorical variables of gender, age group, nationality and ethnicity were tested using chi-squared tests of independence. Inclusion offence proportions were tested one by one also using chi-squared tests of independence. For examining differences between means, we tested the underlying distributional assumption of Normality using quantile-quantile plots, and used the Kruskal-Wallis test if non-normality was found, and a one- way ANOVA otherwise. Where significance was determined, a Bonferroni post-hoc test was used to determine which of the offender groups were significantly different from each other.

We used an alpha level of 0.05 for all statistical tests. All statistical analysis was carried out in R using the R function kendall in the library irr for calculation of the Kendall concordance test, and function kruskal . test for the Kruskal-Wallis non-parametric tests of means.

\section{Results}

The 4109 individuals designated as organised crime offenders from the PNC between 2007-2010, comprised $0.2 \%$ of the overall offender sample. These individuals 
amassed 91,528 sanctions during this period (mean 22.3; SD 26.5). There was a significant difference in the rank order of the 16 police agencies (Table 1) according to whether they were ranked for numbers of organised crime offenders or overall recorded crime, $\mathrm{W}=0.912, \chi^{2}(15, \mathrm{~N}=16)=27.4, \mathrm{p}=0.026$.

\section{TABLE 1 HERE}

A chi-squared test of independence (Table 2) showed a significant relationship of sample group with gender $\chi^{2}(2, N=12,308)=880.8, p=<0.001$, with higher proportions of males in the two serious crime groups. Chi-squared tests of independence (Table 2) also examined the relationship between ethnicity and nationality with sample group. There was a highly significant relationship of nationality with crime group, with organised crime offenders less likely to be of UK nationality $\chi^{2}(4, N=12,308)=112.5, p=<0.001$. Similarly, there was a significant relationship of ethnicity with sample group, $\chi^{2}(12, N=12,308)=832.7, p=<0.001$, with organised crime offenders less likely to be white northern European.

\section{TABLE 2 HERE}

There was a significant difference between the ages at the inclusion offence across sample groups, Kruskal Wallis $\chi^{2}(2, N=12,308)=301.2, p=<0.001$, with general offenders younger than the serious offending and organised crime samples. 
We tested the differences in the proportion of each inclusion offence across the sample group separately for each crime type, as offenders could be sanctioned for more than one crime type at the target offence. Table 3 shows that the proportions were significantly different for each crime type. Drug offences $\chi^{2}(2$, $N=12,308)=4231.7 ; p<0.001$ and fraud offences $\chi^{2}(2, N=12,308)=57.0 ; p<0.001$ were more likely to occur in the organised crime group; whereas all other offence types were less likely to be organised crime offences.

\section{TABLE 3 HERE}

Finally, we looked at other criminal history variables (examining only those with UK nationality, as those with non-UK nationality were unlikely to have full criminal history information). Table 4 shows significant differences between the three samples in age at first offence, Kruskal Wallis $\chi^{2}(2, N=10198)=349.2, p=<0.001$, with general crime offenders older on their first offence than the organised crime and serious crime groups. The number of prior sanctions, Kruskal Wallis $\chi^{2}(2$, $\mathrm{N}=10198)=2146.2, \mathrm{p}=<0.001$ and prior sanction occasions Kruskal Wallis $\chi^{2}(2$, $\mathrm{N}=10198)=2137.5, \mathrm{p}=<0.001$ were both significantly different across the sample groups, with lower numbers of prior sanctions in the general crime sample.

TABLE 4 HERE

\section{Discussion}


To mirror the research objectives the results are discussed in three stages, before placing them in the context of organised crime research.

The spatial distribution of offences

Table 1 shows, in rank order, the top sixteen British police forces in terms of convicted organised crime offenders, across the four-year period. The table also displays the ranking of these 16 forces in relation to overall recorded crime, with the rankings being statistically different. Whilst it could be expected that the top five police forces for general recorded crime also showed the highest level of organised crime convictions, there were also some surprises. Some Police Forces illustrated a much higher ranking for organised crime than general recorded crime, and viceversa. For example, the table shows police forces who are ranked as 7, 8, 12 and 14 in the general crime classification are omitted from the top 16 of organised crime prosecutions. Although this relates to the UK, the implications are transferable as for the first time a methodology has been developed that can provide an indication of where detected organised crime offenders are concentrated. This suggests that organised crime is disproportionally concentrated in specific population centres and does not necessarily mirror general crime patterns.

\section{Offender demographics}

The analysis then compared all three offender groups on gender, age, nationality and ethnicity characteristics (table 2). The first analysis shows both organised crime and serious crime offenders were predominantly male (95\%), which was markedly higher than general crime offenders (78\%). Further, the mean age for the organised 
crime offender at their inclusion offence (sanction between 2007 and 2010) was 32 years, similar to serious crime offenders (31 years), but approximately three years older than the general crime offenders (28 years).

Although nationality had not been recorded for approximately $5 \%$ of the organised crime sample, UK nationals were in the majority, accounting for around 4 out of 5 individuals in each of the three groups (table 2). However more non-UK nationals $(13 \%)$ were in the organised crime group, than serious crime (9\%) and general (10\%) offender groups. There was no difference in the gender balance across nationality, with $5 \%$ of both UK and non-UK national organised crime offenders being women.

White Europeans were the majority in each offender sample, although they accounted for fewer of the organised crime offenders (56\%) than serious crime (73\%) or general crime (81\%) samples. Offenders whose ethnicity was recorded as 'Black' (23\%) or 'Asian' (15\%) together accounted for more than one third of organised crime offenders in the analysis. The differences between the groups on grounds of ethnicity were found to be highly significant (table 2).

To obtain an overview of the type of offences that led to individuals being selected as organised crime offenders, the inclusion offences were allocated to one of ten offence categories (table 3). Drug offences distinguish the groups: whilst $73 \%$ of inclusion offences relate to this theme for organised crime offenders, this is only $19 \%$ for serious crime and $10 \%$ for general crime offenders. Further, although small in number, fraud and forgery offences were more common inclusion offences in the 
organised crime group (5\%). Violence was more common in the serious (26\%) and general crime (34\%), than the organised crime sample (9\%). The same pattern was seen with acquisitive crimes (robbery, burglary and theft), which rarely featured in organised crime offenders. Overall, inclusion offences for the general and serious crime offender samples were more evenly distributed across the ten offence categories compared with the organised crime sample.

\section{Offending patterns over the criminal life course}

We now discuss the offending patterns in more detail. It has been suggested that due to the more complex and collaborative nature of organised crime, the crime pathways are different for organised crime offenders than general crime offenders (Kleemans \& de Poot, 2008). All non-UK offenders (and those of unknown nationality) were excluded, as it is unlikely the full criminal histories of these groups are recorded on the PNC. This left 3,360 offenders ( $82 \%$ of the original OC offender population).

Table 4 shows whilst both the organised and serious crime offenders had a mean age of first sanction in their late teenage years (19.0 and 18.8 years respectively), these were significantly younger than the mean age for general offenders (21.7 years). Additionally, only $5.2 \%$ of the organised crime group started their criminal career at age 35 years or older, compared to $7.1 \%$ of serious offenders and $11.5 \%$ of general offenders. 
The time from onset to the inclusion offence is also shown in table 4 . This is over 12 years for both the organised crime sample and the serious crime sample, around double the time from onset to inclusion for the general crime sample. Additionally, although many organised crime offenders have criminal careers that appear to span a considerable number of years, it is worth noting that a minority of organised crime offenders (10\%) had no sanctions prior to their inclusion offence.

An alternative way of examining criminal careers of offenders is to consider the total volume of sanctions acquired between the onset of offending and the inclusion offence. Table 4 shows the average number of prior sanctions and convictions received by offenders in each group sample. The organised crime offenders had an average of 9 sanction occasions and 21 offences before their inclusion offence for organised crime. Indeed there is a substantial history of prior contact with the Criminal Justice System for the majority of organised crime offenders before their inclusion offence.

When comparing across the three groups, the general crime offenders had far less prior contact (nearly $45 \%$ having no prior contact with the criminal justice system), than the serious and organised crime offenders. However, serious crime offenders were somewhat more prolific in terms of prior proven offending than the organised crime offenders. On average, they had slightly more contact with the criminal justice system than the organised crime offenders before the inclusion offence, recording a marginally higher average number of sanction/conviction occasions. The difference was more marked in terms of the average number of sanctions/convictions they 
experienced ( 27 sanctions for serious crime offenders compared to 21 for the organised crime offenders). However, on balance, the organised crime sample bears closer resemblance to the serious crime sample in terms of the volume of prior sanctions. Interestingly, this analysis was repeated for the non-UK organised crime offenders who had been removed from the sample. This showed that the majority (58\%) had also been convicted of at least one offence in England and Wales prior to their inclusion offence. So while it is not possible to be sure of the full extent of the criminal histories of this group prior to their arrival in the UK, almost six in ten were known to UK police agencies before their inclusion offence.

In summary, although more distinct from the 'general' than the 'serious crime' offender control samples, the results indicate that the methodology has identified a sub set of organised crime offenders. The sample can be distinguished from others on various measures including: diversity in nationality and ethnicity, criminal onset age, criminal recidivism and type of offending.

The use of official databases in organised crime research We now place these findings in context. Historically the measurement of organised crime has been problematic due to issues surrounding: (i) the identification of the concept; (ii) the definition of its constituent parts; (iii) its structure; and (iv) the type of offender who commits it. This paper does not wish to minimize the importance of this academic debate. However it argues, even with these difficulties, new methods can be devised to measure organised crime thereby improving the evidence base on which to improve policy. 
It is readily accepted that as this is the first attempt to establish a new methodology, limitations exist within the methodology. First, the PNC data provides evidence of proven offending not actual offending and it is not known how these subjects differ from undetected offenders. Secondly, although reactive and fortuitous arrests (e.g. random stop and search), are added to proactive arrests, some level of selection bias remains (mirroring Criminal Justice decision making). Thirdly, there are restrictions emanating from the selection criteria used. In terms of co-offending it is not possible to establish from the PNC data when a crime has been perpetrated with another; it can only indicate when someone is prosecuted with a co-defendant. Similarly using the three year sentence length will oversample recidivists, as the justice system gives longer sentences to repeat offenders. However overall it is believed the approach provides a high threshold for inclusion, with a small likelihood of false positives and a larger likelihood of false negatives. As such, although supplying a large sample of organised crime offenders (over 4000) this will serve to underestimate the actual number of offenders linked to organised crime.

These concerns aside the results show the selection criteria used has facilitated a pragmatic and legitimate approach to differentiate organised crime offenders from others within the system. Although requiring further development the initial analysis provides valuable empirical evidence to improve the evidence base for policy and tactical interventions. For example this study provides a method to assess the level of organised crime prosecutions $(0.2 \%)$, when compared with the general offender population. This reinforces the point that a small number of offenders can 
have a disproportionate impact in terms of the harm they can cause. The study also indicates the geographic locations these prosecutions are most likely to occur and, as with general crime, this distribution is not random. Although the results show that the distribution of organised crime prosecutions generally mirror general crime, anomalies are present, suggesting spatial analysis would be a useful tool in understanding the specific threat. For example some lesser populated but affluent areas had a low level of general crime but a disproportionately higher level of organised crime. Further, on initial inspection, locations with maritime ports also appeared to have a higher association with organised crime convictions. This generates the question as to whether organised crime concentrates around specific geographic or demographic variables. Further, it could provide a new method of assessing police force areas in relation to organised crime outputs and outcomes (prosecutions and sentencing). Although caution should be raised in terms of measuring quantity over quality, it provides further information in discussions over resources, and opens up the potential for specific agencies to develop centres of excellence for specific categories of organised crime.

The results also provided a richer picture of the average organised crime offender and how they compare with others to provide important information for the policy maker and practitioner. For example organised crime offenders appear a much more diverse group (in terms of nationality and ethnicity) than comparison groups. Specifically the research found non-UK offenders constitute $13.9 \%$ of the sample of organised crime offenders, which is slightly higher than the $11.4 \%$ level of foreignborn individuals within the UK population (Rienzo \& Vargas-Silva, 2013). However 
the majority (58\%) of these non-UK offenders had already been convicted of an offence in the UK prior to their organised crime offence, identifying them as a small but significant group, for which tailored interventions may be possible.

Using the UK Home Office organised crime family categories it also became apparent that organised crime prosecutions are dominated by drug offences (73.8\%), followed by violent criminal activity (11.1\%), commodity importation/ counterfeiting (6.8\%), organised theft (5.2\%), and fraud/ financial crime (4.9\%). The remaining five categories account for only $1 \%$ of prosecutions. It should be highlighted that the methodology used to define organised crime (especially the stipulation of 'cooffending'), may affect some lesser used offence categories (for example money laundering), however the general direction of the findings is thought to be accurate, based on discussions with stakeholders. Such information may also be of assistance to strategic leaders, when considering particular organised crime priorities and the effectiveness of legislation.

The UK national database also allowed analysis of offenders and their criminal pathway allowing further consideration for policy makers and researchers alike. Age is a significant variable, with $40 \%$ of organised crime offenders receiving a criminal conviction or caution prior to 16 years. This illustrates a significant number of early onset and persistent offenders, who later become involved in organised crime. There is already a significant level of research surrounding early intervention to prevent future negative outcomes (Farrington et al. 2001), and the potential exists for organised crime to be brought into this process. Conversely, there are $10 \%$ of 
offenders whose first criminal sanction is for an organised crime offence, when they reach 30 years or beyond. This 'adult late onset' offender has previously been highlighted in Dutch organised crime studies (van Koppen et al. 2010), and is not a pattern generally reflected in the wider offending population. Given that these inclusion offences involve planning and collaboration, and receive a three year sentence or more, the proportion found to have no prior sanction event appears significant and worthy of further exploration. Initial discussions with law enforcement personnel have generated two possible explanations: the offender is sophisticated and has managed to remain invisible; or the offender is a professional facilitator with specific skills or legitimate business interests (e.g. solicitor or transporter), enticed into illegality by an organised crime group. Further research can provide richer understanding as to how offenders become embroiled in such serious offending to disrupt and prevent offending. This knowledge can be used to generate disruptive and preventative strategies that seek to change an offenders perception of involvement in the organised crime activity (Kirby, 2013).

\section{Conclusion}

In conclusion, as Brocklesby (2014) warns, complexity can bring inertia. This paper suggested the academic disagreement concerning a common definition had diluted the empirical evidence available to policy makers and practitioners. Whilst accepting the importance of this conceptual discussion, this study suggests a new and supplementary approach to bridge the gap between theory and practice. It illustrates the potential to gather empirical understanding of organised crime from existing general data sets across different legislative areas, prior to expending 
resources on new sets. From the literature, this study proposed three simple and transferable criteria to identify organised crime offenders: serious crime, specific offence types, and co-offending. Testing these criteria using the UK national offender database (PNC) it found the variables sensitive enough to distinguish this type of offender from others. Indeed using a 'offence based' dataset, rather than the 'offender based' dataset that normally emerge from pro-active police investigations provides a much richer overview. Organised crime offenders can be differentiated on measures such as: criminal onset age, criminal recidivism, and offence type. This analysis prompts further questions to develop understanding in this field, which in turn could be used to more effectively deliver preventative and disruptive tactics. Whilst accepting the methodology has flaws, it is felt these are outweighed by the benefits provided to policy makers and practitioners involved in the policing of organised crime.

\section{Acknowledgements}

Our thanks to Michael Skidmore who provided support and logistics.

This paper is in memory of our dear friend and colleague Professor Keith Soothill, who was involved with this project, and who sadly passed away in February 2014. 


\section{References}

Australian Crime Commission (2013), "Organised Crime in Australia 2013". Available at https://www.crimecommission.gov.au/sites/default/files/ACC\%200CA\%2020131.pdf, (Accessed 27.5.15)

Brocklesby, J. (2012), "Using the Viable Systems Model to examine multi-agency arrangements for combatting transnational organised crime", Journal of the Operational Research Society (2012) 63, 418-430.

Cole, P. (1979), "The evolving case-control study". Journal of Chronic diseases, 32 (12), 15-27.

Cressey, D. (1969) Theft of the Nation: The structure and operations of organized crime in America: Harper \& Row Publishing: New York

Duijin, P.A., Kashirin, V., \& Sloat, P.M.A. (2014), "The relative ineffectiveness of criminal network disruption", Scientific Reports, 4 (4238), 1-15

Edwards, A. \& Gill, P. (2003), Transnational Organized Crime: Perspectives on Global Security, Routledge: London.

Farrington, D.P., Loeber, R., and Kalb, L.M. (2001), "Key research and policy issues". In Child Delinquents: Development, Intervention and Service Needs, edited by R. Loeber and D.P. Farrington. Sage Publications, Inc.: Thousand Oaks, CA. pp. 385-394. Finckenauer, J.O. (2005) "Problems of Definition: What is Organized Crime?" Trends in Organized Crime, 8(3), 63-83.

Galtung, F. (2006), "Measuring the immeasurable: Boundaries and functions of (macro) corruption indices", in A.Shacklock et al. (eds), Measuring corruption. Ashgate: Aldershot.

Gilmour, S. (2008) “Understanding Organized Crime: A Local Perspective”, Policing, 2(1), 18-27.

Hobbs, D. (1998), "Going down to the 'Glocal': The local context of Organized Crime", Howard Journal of Criminal Justice, 37 (4), 407-422.

Home Office (2013) Serious and Organised Crime Strategy, Available at https://www.gov.uk/government/publications/serious-organised-crime-strategy. (Accessed 2.3.14)

Kirby, S. (2013) Effective Policing: Implementation in theory and practice, Palgrave MacMillan: Basingstoke.

Kleemans, E.R. \& de Poot, C.J. (2008), "Criminal Careers in Organized Crime and Social Opportunity Structure", European Journal of Criminology, 5(1), 69-98.

Levi, M. (2012), "Organised Crime" in M.Maguire, R.Morgan \& R.Reiner (eds.) Oxford Handbook of Criminology ( $5^{\text {th }}$ Ed.), Oxford: Oxford University Press.

Levi, M. \& Maguire, M. (2004) "Reducing and preventing organised crime: An evidence based critique", Crime Law \& Social Change, 41, 397-469.

NCIS (2005) UK Threat Assessment Report, London: National Crime Intelligence Service. 
Rienzo, C. \& Vargas-Silva, C. (2013), Migrants in the UK: An Overview, $3^{\text {rd }}$ Revision. Oxford: Migration Observatory. Available at

http://www.migrationobservatory.ox.ac.uk/. (Accessed 27.4.14)

Savona, E. (2014), “Organised crime numbers", Global Crime, 15(1-2), 1-9.

Sheptycki, J. (2003), "The governance of organised crime in Canada", The Canadian Journal of Sociology, 28(4), 489-516.

Smith, D. (1991), "Wickersham to Sutherland to Katzenbach: Evolving an 'official' definition of organized crime", Crime, Law and Social Change, 16(2), 134-154.

Standing, A (2003), Rival Views of Organized Crime, Pretoria: Institute for Security Studies, Monograph 77.

Sullivan, C.J. \& McGloin, J.M. (2014), "Looking back to move forward: Some thoughts on measuring crime and delinquency over the past 50 years", Journal of Research in Crime \& Delinquency, 51 (4), 445-466.

Transparency International (2004), "Report on the global corruption barometer 2004", Available at www.transparency.org. (Accessed 2.3.15)

Tusikov, N. (2012), "Measuring organised crime-related harms: exploring five policing methods", Crime Law \& Social Change, 57, 99-115.

United Nations Centre for International Crime Prevention (2000), “Assessing Transnational Organized Crime: Results of a pilot survey of 40 selected organized criminal groups in 16 countries", Trends in Organized Crime, 6(2), 48-49.

van der Heijden, T. (1996). "Measuring Organized Crime in Western Europe". In Milan, P. (ed.) Policing in Central and Eastern Europe: Comparing First Hand Knowledge with Experience from the West. College of Police and Security Studies: Slovenia.

van Dijk, J. (2007), "The International Crime Victims Survey and Complementary Measures of Corruption and Organised Crime", in M.Hough \& M.Maxfield (eds.), Surveying Crime in the $21^{\text {st }}$ Century, Crime Prevention Studies 22. Criminal Justice Press: Monsey, NY:.

van Koppen, M.V., de Poot, C.J., \& Blokland, A.J. (2010), “Comparing Criminal Careers of Organized Crime Offenders and General Offenders", European Journal of Criminology, 7(5) 356-374.

von Lampe, K. (2012), "Transnational organized crime challenges for future research", Crime Law and Social Change, 38, 179-194.

von Lampe, K. (2015) Definitions of Organized Crime. Available at http://www.organized-crime.de/organizedcrimedefinitions.htm. (Accessed 8/6/15).

Weenink, S.W., Huisman, S., van der Laan, F.J. (2004), Crime without frontiers: Crime Pattern Analysis Eastern Europe, 2002-2003; Korps Landelijke Politiediensten:

Driebergen, N.L.

World Economic Forum (2004), The global competitiveness report 2003-2004. Oxford University Press: New York. 
Table 1: Comparing the 16 highest police force areas in terms of OC prosecutions (20072010) compared with their ranking of total recorded crime.

\begin{tabular}{|c|c|c|c|}
\hline & $\begin{array}{l}\text { Number of } \\
\text { organised } \\
\text { crime } \\
\text { offenders } \\
\end{array}$ & $\begin{array}{c}\text { Percent of all } \\
\text { organised } \\
\text { crime } \\
\text { offenders } \\
\end{array}$ & $\begin{array}{l}\text { Rank of Police force } \\
\text { areas in terms of } \\
\text { recorded crime } \\
2007-10\end{array}$ \\
\hline 1.Metropolitan & 816 & 19.9 & 1 \\
\hline 2. West Yorkshire & 303 & 7.4 & 4 \\
\hline 3. Greater Manchester & 293 & 7.1 & 2 \\
\hline 4. West Midlands & 191 & 4.6 & 3 \\
\hline 5. Thames Valley & 183 & 4.5 & 5 \\
\hline 6. South Wales & 183 & 4.5 & 13 \\
\hline 7. Merseyside & 181 & 4.4 & 10 \\
\hline 8. Hampshire & 174 & 4.2 & 6 \\
\hline 9. Sussex & 123 & 3.0 & 15 \\
\hline 10. Kent & 114 & 2.8 & 9 \\
\hline 11. West Mercia & 102 & 2.5 & 21 \\
\hline 12. Surrey & 96 & 2.3 & 25 \\
\hline 13. Northumbria & 93 & 2.3 & 17 \\
\hline 14. Cleveland & 88 & 2.1 & 29 \\
\hline 15. Devon \& Cornwall & 86 & 2.1 & 16 \\
\hline 16. Lancashire & 83 & 2.0 & 11 \\
\hline All other forces $(\mathrm{N}=27)$ & 1,000 & 24.3 & \\
\hline Total & $N=4,109$ & 100.0 & \\
\hline
\end{tabular}


Table 2: Offender group by socio-demographic characteristics

\begin{tabular}{|c|c|c|c|c|}
\hline & $\begin{array}{l}\text { Organised } \\
\text { crime } \\
\text { offenders }\end{array}$ & $\begin{array}{l}\text { Serious } \\
\text { crime } \\
\text { offenders }\end{array}$ & $\begin{array}{l}\text { General } \\
\text { offenders }\end{array}$ & $p$-value \\
\hline Male offenders & $95.0 \%$ & $95.7 \%$ & $78.1 \%$ & $<0.001$ \\
\hline $\begin{array}{l}\text { Nationality } \\
\text { UK } \\
\text { Non-UK } \\
\text { Unknown }\end{array}$ & $\begin{array}{c}81.8 \% \\
13.1 \% \\
5.2 \%\end{array}$ & $\begin{array}{c}86.0 \% \\
9.1 \% \\
4.9 \%\end{array}$ & $\begin{array}{c}80.8 \% \\
10.0 \% \\
9.2 \%\end{array}$ & $<0.001$ \\
\hline $\begin{array}{l}\text { Ethnicity } \\
\text { Asian } \\
\text { Black } \\
\text { Chinese/Japanese/ } \\
\text { South East Asian } \\
\text { Middle Eastern } \\
\text { White - North } \\
\text { European } \\
\text { White - South } \\
\text { European } \\
\text { Unknown }\end{array}$ & $\begin{array}{l}15.0 \% \\
23.3 \% \\
2.3 \% \\
1.1 \% \\
53.9 \% \\
2.2 \% \\
2.2 \%\end{array}$ & $\begin{array}{c}7.5 \% \\
17.1 \% \\
0.9 \% \\
0.5 \% \\
\\
70.7 \% \\
\\
1.8 \% \\
1.5 \%\end{array}$ & $\begin{array}{l}5.4 \% \\
8.0 \% \\
0.8 \% \\
0.8 \% \\
79.6 \% \\
1.8 \% \\
3.6 \%\end{array}$ & $<0.001$ \\
\hline $\begin{array}{l}\text { Mean age at inclusion } \\
\text { (Std. Dev) }\end{array}$ & $\begin{array}{c}31.7 \\
(10.39)\end{array}$ & $\begin{array}{c}31.5 \\
(11.72)\end{array}$ & $\begin{array}{c}28.7 \\
(12.14)\end{array}$ & $p<0.001^{2}$ \\
\hline $\mathrm{N}$ & 4109 & 4109 & 4090 & \\
\hline
\end{tabular}


Table 3: Inclusion offences: proportion of offenders sanctioned for each type of offence, by group type

\begin{tabular}{|c|c|c|c|c|c|c|c|}
\hline & \multicolumn{2}{|c|}{$\begin{array}{l}\text { Organised } \\
\text { crime } \\
\text { offenders }\end{array}$} & \multicolumn{2}{|c|}{$\begin{array}{c}\text { Serious crime } \\
\text { offenders }\end{array}$} & \multicolumn{2}{|c|}{$\begin{array}{l}\text { General } \\
\text { offenders }\end{array}$} & \multirow[t]{2}{*}{$\begin{array}{l}\chi^{2} \text { test and } p- \\
\text { value }\end{array}$} \\
\hline & $\%$ & $N$ & $\%$ & $\mathrm{~N}$ & $\%$ & $\mathrm{~N}$ & \\
\hline $\begin{array}{l}\text { Violence against the } \\
\text { person }\end{array}$ & 10.7 & 439 & 25.9 & 1,063 & 33.8 & 1,381 & $\begin{array}{r}\chi^{2}(2)=629.4 \\
p<0.001\end{array}$ \\
\hline Sexual offences & 0.9 & 37 & 14.5 & 597 & 1.2 & 48 & $\begin{array}{r}\chi^{2}(2)=952.3 \\
p<0.001\end{array}$ \\
\hline Robbery & 0.0 & 0 & 20.2 & 831 & 0.9 & 38 & $\begin{array}{r}\chi^{2}(2)=1631.5 ; \\
p<0.001\end{array}$ \\
\hline Burglary & 0.0 & 0 & 15.3 & 629 & 2.1 & 84 & $\begin{array}{r}\chi^{2}(2)=1039.1 ; \\
p<0.001\end{array}$ \\
\hline $\begin{array}{l}\text { Theft and handling } \\
\text { stolen goods }\end{array}$ & 6.3 & 259 & 3.2 & 113 & 17.2 & 702 & $\begin{array}{r}\chi^{2}(2)=580.1 ; \\
p<0.001\end{array}$ \\
\hline Fraud and forgery & 5.2 & 214 & 2.1 & 85 & 4.0 & 163 & $\begin{array}{r}\chi^{2}(2)=57.0 \\
p<0.001\end{array}$ \\
\hline Drug offences & 73.1 & 3,005 & 18.8 & 771 & 10.4 & 427 & $\begin{array}{r}\chi^{2}(2)=4231.7 \\
p<0.001\end{array}$ \\
\hline Criminal damage & 0.0 & 2 & 2.0 & 83 & 10.4 & 427 & $\begin{array}{r}\chi^{2}(2)=626.0 \\
p<0.001\end{array}$ \\
\hline Driving offences & 0.0 & 0 & 0.1 & 5 & 15.4 & 629 & $\begin{array}{r}\chi^{2}(2)=1311.6 \\
p<0.001\end{array}$ \\
\hline Other offences & 7.0 & 286 & 4.7 & 195 & 16.9 & 692 & $\begin{array}{r}\chi^{2}(2)=399.6 \\
p<0.001\end{array}$ \\
\hline Overall $\mathrm{N}$ & & 4109 & & 4109 & & 4090 & 13108 \\
\hline
\end{tabular}

Percentages will sum to more than 100 as some offenders receive convictions for more than one type of offence at the inclusion date. 'Other' offences are predominantly breach, bail, and public order offences. 
Table 4: Criminal history measures by offender group (UK offenders only)

\begin{tabular}{|c|c|c|c|c|}
\hline & $\begin{array}{l}\text { Organised } \\
\text { crime } \\
\text { offenders } \\
(\mathrm{N}=3360)\end{array}$ & $\begin{array}{l}\text { Serious } \\
\text { crime } \\
\text { offenders } \\
(\mathrm{N}=3533)\end{array}$ & $\begin{array}{l}\text { General } \\
\text { crime } \\
\text { offenders } \\
(\mathrm{N}=3305)\end{array}$ & $p$-value \\
\hline $\begin{array}{l}\text { Mean age at first sanction } \\
\text { (std.dev) }\end{array}$ & $\begin{array}{c}19.0 \\
(7.96)\end{array}$ & $\begin{array}{c}18.8 \\
(10.00)\end{array}$ & $\begin{array}{c}21.7 \\
(10.65)\end{array}$ & $p<0.001^{1}$ \\
\hline $\begin{array}{l}\text { Mean time in years from onset } \\
\text { to inclusion (std.dev) }\end{array}$ & $\begin{array}{c}12.6 \\
(10.30)\end{array}$ & $\begin{array}{c}12.5 \\
(10.40)\end{array}$ & $\begin{array}{c}6.5 \\
(9.33)\end{array}$ & $p<0.001^{1}$ \\
\hline $\begin{array}{l}\text { Mean number of prior sanction } \\
\text { occasions (court appearances, } \\
\text { police caution occasions) } \\
\text { (std.dev) }\end{array}$ & $\begin{array}{l}9.2 \\
(9.08)\end{array}$ & $\begin{array}{c}11.1 \\
(10.23)\end{array}$ & $\begin{array}{c}3.3 \\
(6.13)\end{array}$ & $p<0.001^{1}$ \\
\hline $\begin{array}{l}\text { Mean number of prior sanctions } \\
\text { (std.dev) }\end{array}$ & $\begin{array}{l}21.3 \\
(27.05)\end{array}$ & $\begin{array}{c}27.2 \\
(32.71)\end{array}$ & $\begin{array}{c}6.8 \\
(16.06)\end{array}$ & $p<0.001^{1}$ \\
\hline $\begin{array}{l}\text { Percentage of offenders with no } \\
\text { prior sanction. }\end{array}$ & $9.9 \%$ & $10.1 \%$ & $44.8 \%$ & \\
\hline$N$ & 3360 & 3533 & 3305 & 10198 \\
\hline
\end{tabular}

${ }^{1}$ Kruskal-Wallis test 


\section{Likely Offences}

\begin{tabular}{|l|}
\hline Offence description \\
\hline Trading in firearms without being registered. \\
\hline $\begin{array}{l}\text { Person has Class A, class B or class unspecified drugs in his/her } \\
\text { possession on a ship }\end{array}$ \\
\hline Unlawful importation or exportation of a controlled drug \\
\hline $\begin{array}{l}\text { Production of or being concerned in the production of a controlled } \\
\text { drug }\end{array}$ \\
\hline Supplying or offering to supply the class B drug cannabis \\
\hline Concealing, transferring or using the proceeds of drug trafficking \\
\hline $\begin{array}{l}\text { Controlling a brothel/ controlling a child aged 13-17 for } \\
\text { prostitution or pornography }\end{array}$ \\
\hline $\begin{array}{l}\text { Arranging or facilitating arrival of a person into or within the UK } \\
\text { for sexual exploitation }\end{array}$ \\
\hline $\begin{array}{l}\text { Trafficking people into or within the UK for the purpose of } \\
\text { exploitation. }\end{array}$ \\
\hline Possess materials or dies to make counterfeit coin or note; \\
\hline Failure to disclose person involved in money laundering \\
\hline Cartel offences \\
\hline Blackmail and Extortion \\
\hline Kidnapping \\
\hline Hijacking of train, ship or aircraft \\
\hline $\begin{array}{l}\text { Interference with contractual relationships so as to harm animal } \\
\text { research organisations; intimidation of researchers }\end{array}$ \\
\hline
\end{tabular}

\section{Possible Offences}

Fraudulently printing stamps, make or adapt articles with fraudulent intent (eg hacked decoder boxes)

Unauthorised modification of computer material

Counterfeiting money, prescriptions or materials to make these; other forgery

Hallmarking offences

Conveying a list A article into prison

Selling to person without firearms certificate, falsifying

certificate, modification or conversion of firearm, possession or distribution of prohibited weapons, supply of firearms to person

denied them, possession of firearms disguised as other object,

unlawful importation or exportation of weapons or ammunition.

Offences against VAT, Car tax, fuel tax; evasion of importation

duty

Register falsification

Cannabis production

Supplying or offering to supply Class A . Class B or Class C

drug except Cannabis

Possession with intent to supply Class A B or C drug

Frauds by company directors; disqualified person acting as director

Accounting record frauds; false accounting

Conspiracy to defraud ; Land sale fraud; document fraud or

concealment

Insider dealing

Dishonestly Retaining A Wrongful Credit

False representation; failure to disclose information; abuse of position; possession of articles

Suppression of information regarding a rightful claim, or false information for a false claim

Offences in relation to bankruptcy and Insolvency

Cheating or helping other to cheat at gambling

Fraudulent licences and certification for medical products

False or Misleading Statements in financial markets

Fraudulent evasion of duty

Possess another person's identity document 
Fraudulent provision of immigration advice

Assisting unlawful immigration to member state; Helping

asylum-seeker to enter the UK; Assisting entry to UK in breach

of deportation order or exclusion order; (making or using or

attempting to use a false registration card; forged immigration

stamp.

Unlicenced gangmaster; fraudulent gangmaster documentation

Concealing criminal property; aiding the concealment;

possessing, acquiring criminal property.

Motor vehicle theft

Receiving stolen goods

Assisting in the disposal, retention, realisation of stolen goods

Unauthorised access to computer system with intent

Causing or inciting sexual activity in children under 13

Arranging or facilitating the commission of a child sex offence

Causing inciting, arranging or facilitating child prostitution or

pornography aged 17 or under

Indecent photographs of children

Causing or inciting prostitution for gain; controlling a prostitute

for gain.

Prohibition of publication of obscene matter.

Failure to disclose money laundering by crime investigation

officer; prejudicing investigation, disposal of documents relating

to investigation

Conspiracy to murder; burning, maiming by explosion, causing

explosion with intent to do grievous bodily harm; possession of

explosives with intent to endanger life; threat of using

explosives

Possession of firearms with intent to endanger life or injure

property.

Using a chemical weapon

Use of noxious substances or things to cause harm or intimidate

False imprisonment

Detaining and threatening to kill or injure a hostage 